\title{
Mempertahankan Piil Pesenggiri Sebagai Identitas Budaya Suku Lampung
}

\author{
Fitra Endi Fernanda $\left({ }^{1 *}\right)$, Samsuri $\left({ }^{2}\right)$ \\ 12 Department of Civic Education, Graduate School of Universitas Negeri Yogyakarta, Indonesia
}

\begin{tabular}{ll} 
ARTICLE INFORMATION \\
\hline $\begin{array}{l}\text { Submitted } \\
\text { Review }\end{array}$ & $: 23^{\text {th }}$ September, 2019 \\
Accepted & $: 10^{\text {th }}$ November, 2020 \\
Published & $: 15^{\text {th }}$ December, 2020 \\
Available Online & $:$ December, 2020 \\
KEYwORDS & \\
\hline
\end{tabular}

Defending; Cultural Identity; Piil Pesenggiri; Lampung; Tribe

\section{CORRESPONDENCE}

*E-mail: fitrafernanda37@gmail.com

\begin{abstract}
A B S T R A C T
The Lampung tribe is a minority tribe established by Lampung Province. The Lampung Province became a destination for population migration, so Lampung was discussed by Javanese, Sundanese, Balinese and so on. As a minority tribe, the Lampung tribe needs to strengthen its cultural identity among the people so that the cultural values of the Lampung tribe are not lost. Piil Pesenggiri is a philosophy of life that has become the cultural identity of the Lampung tribe. The purpose of this study is to explain the principles of Piil Pesenggiri so that its values can be rebuilt. This article was written in the literature study method with a collection of various sources of books, journals and research on the Piil Pesenggiri. The results show four principles of Piil Pesenggiri that need to be revived, namely juluk adek, nemui nyimah, nemui nyapur and sakai sambyan. Cooperation between all parties, namely traditional leaders, community members, academics and the government, is needed to revive the principles of Piil Pesenggiri.
\end{abstract}

\section{A. PENDAHULUAN}

ndonesia merupakan negara multikultur yang memiliki beragam suku, budaya, bangsa, ras, bahasa, agama dan sebagainya. Keberagaman bangsa Indonesia diakibatkan karena jumlah suku bangsa sangat banyak dan tersebar di seluruh wilayah Indonesia. Berdasarkan data dari Badan Pusat Statistik 2010, jumlah suku bangsa di Indonesia secara keseluruhan mencapai lebih dari 1.300 suku bangsa. Jenis dan persebaran ukuran populasi sangat beragam, misalnya suku Jawa tersebar pada hampir setiap wilayah territorial Indonesia (Na'im \& Syaputra, 2010). Suku Jawa tersebar pada hampir setiap wilayah territorial Indonesia dikarenakan adanya program pemerintah yaitu program transmigrasi. Permasalahan penduduk yang terjadi di Indoensia adalah persebaran penduduk yang tidak merata, sehingga pemerintah Indonesia melanjutkan program yang pernah dilakukan pada masa pemerintahan kolonial Belanda. Sebuah penduduk tidak mungkin homogen karena populasi penduduk terdiri dari individu yang berasal dari beragam suku, bahasa, agama dan budaya yang ada dalam masyarakat terikat dalam suatu negara melalui hubungan yuridis dan politik menjadi sebuah kewarganegaraan (Afriansyah, 2015).

Pada saat pemerintahan kolonial Belanda melakukan pemerataan penduduk di berbagai pulau yang masih sedikit penduduknya untuk memenuhi kebutuhan tenaga perkebunan. Program ini dilanjutkan oleh pemerintahan Indonesia pada masa Orde Baru dalam waktu yang lama. Kebijakan pemerintah ini mengakibatkan komposisi penduduk di daerah yang menjadi tujuan perpindahan lebih heterogen. Penduduk daerah penerima menjadi heterogen yang akan berpengaruh pada akulturasi budaya.

Lampung menjadi salah satu daerah tujuan transmigrasi penduduk dalam waktu yang lama sehingga sebagian besar penduduk Lampung berasal dari pendatang. Sebagian besar penduduk Lampung bukan berasal dari suku Lampung tetapi 
lebih didominasi suku Jawa. Berdasarkan data dari BPS (2010) presentase suku Jawa di Lampung mencapai $61 \%$ di tahun 2000 dan meningkat menjadi $64 \%$ pada tahun 2010. Di Tahun 2000, suku Lampung tidak termasuk tiga suku terbesar yang menempati Provinsi Lampung, tetapi di Tahun 2010 suku Lampung menempati posisi kedua suku terbesar yang menempati Lampung yaitu sebesar $13 \%$. Selain suku Jawa dan Lampung, terdapat suku Bali, Sunda, Batak, dan Minangkabau yang cukup dominan menempati Provinsi Lampung.

Proses transmigrasi ini yang mengakibatkan terjadinya alkuturasi budaya salah satunya melalui jalur perkwinan. Pada masyarakat Saibatin telah mengalami perubahan dari pola bujojogh (patrilokal), menjadi samanda (matrilokal) yang diadopsi dari kebudayaan Minangkabau (Imron \& Pratama, 2020). Menurut Kurniawan dan Rudyansjah (2016) melalui perkawinan ini, telah terjadi pergeseran dari patrilokal ke matrilokal, hal ini tentunya mengaki batkan afiliasi dalam masyarakat Lampung yang cenderung patrinilial berubah menjadi matrilinial, yang tentunya berdampak relasi - relasi kuasa pada kelompok sosial masyarakat. Walaupun alkuturasi budaya memiliki dampak yang baik sebagai bentuk budaya baru, tetapi masyarakat Lampung tetap harus menjaga eksistensinya agar tidak terpinggirkan.

Masyarakat Lampung terdiri dari kelompok adat Pepadun dan adat Saibatin (Lampung Peminggir). Dikarenakan Lampung terdiri dari dua kelompok adat besar yang menghuni satu daerah maka daerah Lampung disebut dengan Sai Bumi Ruwa Jurai. Bahasa yang digunakan masyarakat Lampung terbagi dalam dua dialek yaitu dialek ' $A$ ' dan 'O'. Sebagian besar masyarakat Lampung Saibatin dan sebagian masyarakat Lampung Pepadun seperti masyarakat Way kanan dominan berdialek 'A'. Sedangkan sebagian besar masyarakat Lampung Pepadun dominan berdialek 'O'. Kedua kelompok adat Lampung sama-sama memiliki sistem falsafah hidup yang disebut dengan Piil Pesenggiri. Dalam Kitab Kuntara Raja Niti dijelaskan bahwa Piil Pesenggiri diartikan sebagai rasa malu untuk melakukan pekerjaan hina menurut agama dan memiliki harga diri.

Sebagai sebuah kelompok masyarakat yang independen suku Lampung membentuk dan menghasilkan kebudayaannya sendiri. Menurut Tylor (Jahoda, 2012) budaya merupakan sebuah keutuhan yang didalamnya mencakup kepercayaan, nilai, teknologi, adat istiadat, keterampilan dan kebiasaan sebagai hasil dari pemaknaan manusia dalam kehidupannya, yang diwariskan dan dipelajari secara turun - temurun. Sedangkan (Cole \& Parker, 2011) memandang budaya sebagai sebuah hasil dari perkembangan manusia mempersiapkan substansi pokok dalam berinteraksi dan mengarungi bahtera kehidupannya dengan dunia luar. Piil Pesenggiri merupakan sebuah produk budaya yang dihasilkan oleh suku Lampung, yang perumusannya ditujukan untuk menjadi nilai - nilai fundamental bagi kehidupan sosial masyarakat. Sebagai sebuah produk budaya yang secara turun - temurun diwariskan Piil Pesenggiri menjadi sebuah identitas yang bagi suku Lampung. Identitas budaya menjadi suatu hal yang sangat penting bagi eksistensi sebuah kelompok atau suku, begitu juga dengan keberadaan Piil Pesenggiri bagi suku Lampung. Piil Pesenggiri merupakan sebuah konsepsi nilai yang harus dipertahankan oleh suku Lampung di era moderen saat ini. Hal ini dikarekan eksistensi dari suku Lampung mulai tergeser dengan keberadaan suku lain.

Masyarakat Lampung baik yang berasal dari adat Pepadun maupun Saibatin memiliki sistem falsafah hidup yang telah menjadi identitas budaya suku Lampung dalam kehidupan sosialnya. Falsafah hidup masyarakat Lampung dikenal dengan nama Piil Pesenggiri. Piil Pesenggiri merupakan perpaduan antara nilai - nilai asli masyarakat Lampung yang bersumber dari ajaran kitab Kuntara Rajaniti, Keterem dan Cempala yang dikombinasikan dengan ajaran Islam, dikarenakan Piil Pesenggiri dirumuskan terkait dengan rencana pendirian kesultanan Islam di daerah Lampung. Sebagai sebuah masyarakat yang sebelumnya telah eksis dan memiliki kebudayaan sendiri sebelum terjadi proses Islamisasi masyarakat Lampung sudah memiliki falsafahnya sendiri yaitu Piil.

Menurut Fachruddin (2007) Piil dapat diartikan sebagai harga diri, dengan unsur - unsur yang melekat di dalamnya yaitu harga diri laki - laki adalah wanita, harga diri wanita adalah uang, harga diri anak perempuan adalah kecantikan dan prilaku, dan harga diri anak laki - laki adalah ucapan mereka yang konsekuen (menepati janji). Melalui proses islaminasi yang panjang kata Piil mengalami penambahan oleh pihak kesultanan Cirebon dan Banten menjadi Piil Pesenggiri, kata pesenggiri berasal dari bahasa sunda yaitu pasanggiri yang artinya lomba. Kata ini ditetapkan karena sejalan dengan Islam yaitu Fastabuqu al-khoirot yang berarti, berlombalah kamu dalam kebaikan, sehingga kata piil penggiri dimaknai sebgai sebuah harga diri masyarakat Lampung yang didapatnya melaui proses perlombaan dalam kebaikan.

Melalui proses Islamisasi inilah terjadi perpaduan antara budaya Lampung dan ajaran Islam sehingga menghasilkan Piil Pesenggiri yang telah menjadai falsafah hidup dan identitas masyarakat Lampung. Piil Pesenggiri menjadi warisan budaya masyarakat Lampung yang berlaku bagi seluruh masyarakat. Fachrudin dan Haryadi (1996) mengemukakan bahwa Piil Pesenggiri telah menjadi prinsip dan harga diri. Secara istilah, piil diartikan sebagai prinsip dan pesenggiri sebagai harga diri. Apabila unsur-unsur Piil Pesenggiri dilaksanakan maka harga diri seseorang akan akan baik atau memiliki prestise yang tinggi. Piil Pesenggiri menjadi sebuah model budaya yang menjadi pencapaian khas dari suku Lampung yang nilainya layak untuk dipertahankan dalam menghadapi arus modernisasi. Hal ini senada 
dengan pandangan Gill (2013) bahwa sebuah konsep budaya yang mejadi ciri khas kesukuan dapat ditengarai secara eksplisit maupun implisit serta mampu ditransmisikan melalui simbolik artefak, pengetahuan, nilai-nilai dan norma-norma penting sebagai sebuah bentuk pencapaian khas dari suatu kelompok masyarakat yang sesuai dengan prilaku sosialnya.

Provinsi Lampung saat ini mayoritas ditinggali suku Jawa dan suku Lampung menjadi sendiri menjadi minoritas, karena itu dikhawatirkan Piil Pesenggiri mulai hilang. Piil Pesenggiri perlu diperkuat lagi agar nilai-nilai budayanya tidak luntur. Oleh karena itu tujuan dalam penulisan artikel ini adalah untuk mengetahui bagaimana mempertahankan identitas ulun Lampung melalui Piil Pesenggiri di dalam masyarakat multikultural. Penelitian ini bertujuan untuk menemukan upaya dalam mempertahankant Piil Pesenggiri sebagai identitas budaya masyarakat Lampung agar tidak luntur karena nilai-nilai dari Piil Pesenggiri mulai terpisahkan dari kehidupan social masyarakat Lampung, seiring dengan perubahan-perubahan yang terjadi ketika berinteraksi dengan berbagai macam masyarakat.

\section{B. METODE PENELITIAN}

$\mathrm{F}$ okus kajian dalam penelitian ini menitik beratkan pada masyarakat Lampung Saibatin. Metode yang digunakan dalam penulisan artikel ini menggunakan studi kepustakaan atau studi literature. Studi literature yaitu menelusuri berbagai teori yang diambil dari berbagai buku, artikel jurnal yang berkaitan dengan suku Lampung dan Piil Pesenggiri dan sumber-sumber yang relevan sesuai dengan tema dan permasalahan penelitian seperti buku, jurnal dan hasil penelitian agar menghasilkan studi pustaka sesuai dengan yang diharapkan. Buku menjadi sumber data yang biasa digunakan oleh ahlil sejarah, sastra dan bahasa sebagai bahan analisis (Danial, 2009). Dalam mengkaji berbagai sumber, peneliti memahami, menggali dan menganalisis makna yang didapat dari sumber pustaka.

\section{HASIL DAN PEMBAHASAN}

$\mathrm{B}$ udaya yang melekat dalam sebuah kelompok sosial masyarakat akan menjadi identitas bagi mereka, yang membedakan sebuah kelompok masyarakat dengan kelompok masyarakat lain. Konsep identitas dibentuk dari budaya yang disepakati oleh masyarakat sehingga menjadi sebuah ciri khas bagi individu atau kelompok tertentu. Sebagai sebuah masyarakat yang mandiri suku Lampung telah membentuk dan menjaga eksistensi budaya mereka secara turun - temurun. Produk budaya yang dihasilkan oleh suku Lampung salah satunya adalah Piil Pesenggiri yang telah menjadi falsafah hidup masyarakat Lampung. Namun semakin lama nilai dari Piil Pengenggiri mulai luntur dalam pergaulan masyarakat lampung, karena itulah perlu ada upaya untuk kembali membangun nilai-nilai dari Piil Pesenggiri. Berikut ini akan dijelaskan unsur-unsur dalam Piil Pesenggiri dan bagaimana mempertahankan di dalam masyarakat multikultural.

\section{Unsur- Unsur Piil Pesenggiri}

Nilai-nilai luhur budaya Lampung terlibat dalam keseluruhan adat Lampung seperti sistem kekerabatan, perkawinan, sistem musyawarah dan mufakat, peradilan adat yang berlandaskan filsafat hidup Piil Pesenggiri (Hadikusuma, 1989). Artinya, dalam setiap berpikir, bertindak dan berperilaku masyarakat Lampung harus sesuai dengan filsafat hidup. Mastal (Yusuf: 2013) mengungkapkan bahwa filsafat hidup Piil Pesenggiri sebenarnya sudah dianut oleh masyarakat Lampung sejak zaman Animisme, Hindu-Budha hingga masuknya Islam meskipun telah mengalami perubahan dalam penafsiran. Filsafat hidup Piil Pesenggiri pernah megalami masa kegelapan ketika terjadi perubahan penafsiran yang keliru yaitu mementingkan sikap pragmatik oleh para penguasa yang otoriter dan oleh penjajah kolonialisme dan kapitalis (Yusuf, 2013).

Hal ini menyebabkan mulai memudarnya nilainilai yang terkandung dalam filsafat hidup Piil Pesenggiri yang dinilai negative bagi kehidupan manusia. Seiring dengan kesadaran manusia, filsafat hidup Piil Pesenggiri sudah mulai mengalami perkembangan yang signifikan dalam sistematika dan penafsirannya sejak abad pertengahan $X X$ sampai XXI. Jika zaman dahulu Piil Pesenggiri hanya berlaku pada kalangan raja adat saja, saat ini sudah berlaku bagi seluruh kalangan rakyat. Sehingga perlu pemahaman masyarakat tentang prinsip-prinsip dalam filsfat hidup Piil Pesenggiri. Untuk lebih memahami prinsip-prinsip dalam Piil Pesenggiri dapat dilihat dalam skema gambar 1 . 


\section{Skema 1. Prinsip-Prinsip Piil Pesenggiri}

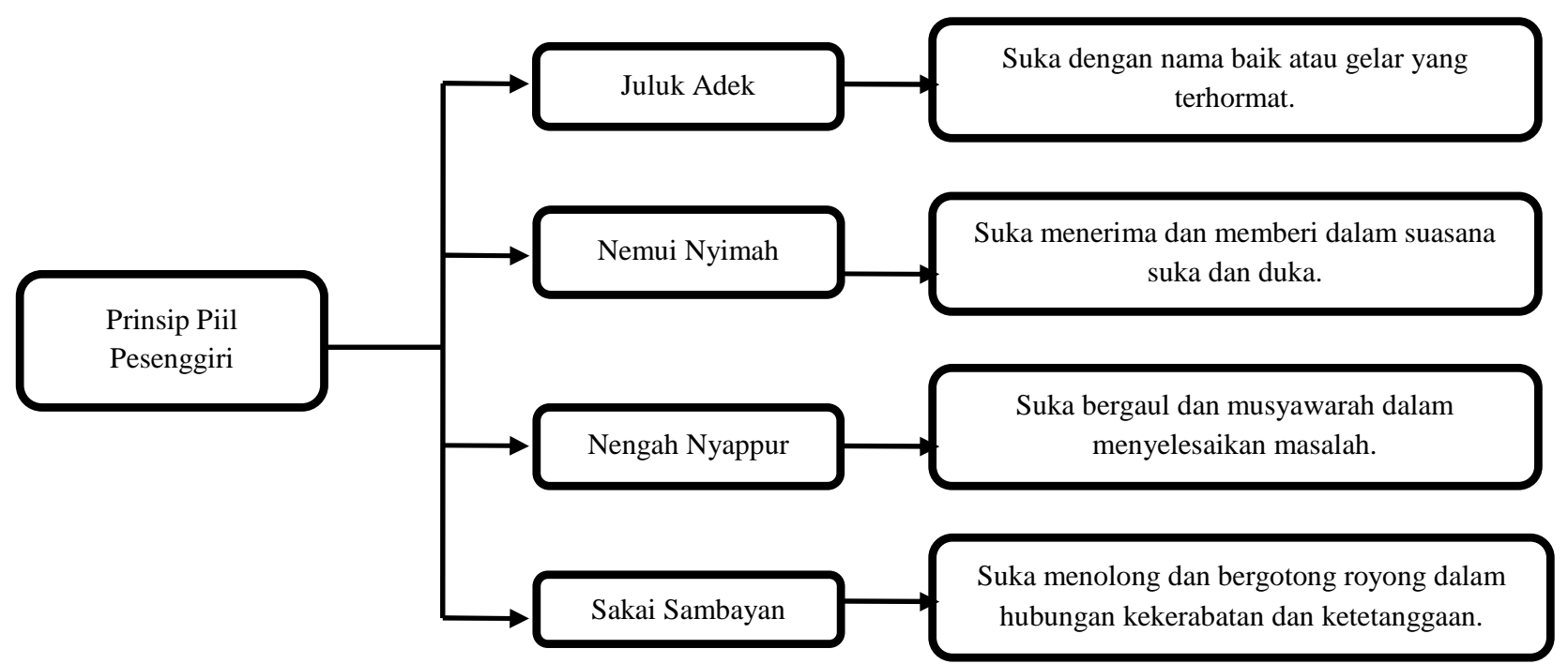

Piil Pesenggiri merupakan suatu keutuhan dari unsur-unsur yang berpedoman pada adat dari leluhur masyarakat Lampung. Terdapat 4 prinsip Piil Pesenggiri yang haris dijunjung tinggi oleh masyarakat Lampung. Prinsip-prinsip ini diterapkan dalam kehidupan sosial masyarakat Lampung pada masyarakat adat saibatin. Apabila ke-4 unsur ini dapat dilaksanakan, maka masyarakat Lampung dapat dikatakan memiliki Piil Pesenggiri. Adapun uraiannya sebagai berikut.

\section{a. Juluk Adek}

Juluk Adek merupakan gelar adat yang diberikan berdasarakan kesepakatan keturunan keluarga masyarakat Lampung. Ada beberapa syarat bagi seseorang untuk mendapatkan gelar tersebut, antara lain status atau kedudukan seseorang itu harus bersangkutan dengan keluarga batih dan mengacu pada gelar atau nama dalam keturuan dua atau tiga tingkat ke atas secara geneologis. Juluk adek menjadi identitas utama yang melekat pada pribadi seseorang, sehingga masyarakat yang telah memiliki juluk adek harus memelihara nama tersebut dengan sebaik-baiknya. Cara memelihara juluk adek diwujudkan dengan pergaulan masyarakat sehari-hari.

Juluk adek menjadi identitas dan sumber motivasi bagi anggota masyarakat Lampung agar menjadi lebih berprestasi dan produktif. Oleh karena itu masyarakat Lampung memelihara nama baik dengan menghindari perbuatan tidak terpuji atau bisa dikatakan memiliki budaya malu ketika berbuat tidak baik.

\section{b. Nemui Nyimah}

Nemui Nyimah secara singkat diartikan sebagai pandai menghormati orang lain. Apabila seseorang yang memiliki harga diri yang tinggi, maka mereka harus pandai menghormati orang lain. Untuk dapat menghormati orang lain, maka seseorang dituntut agar mampu bersikap ramah, santun kepada setiap orang yang ada di sekitar, tidak hanya kepada tamu saja (Haryadi, 1996). Nemui Nyimah juga bisa diartikan sebagai suka menerima dan memberi dalam keadaan suka maupun duka sesuai dengan kemampuan (Ariyani dkk, 2014). Hal ini ditujukan untuk menunjukkan rasa kekeluargaan sehingga tercipta keakraban dan kerukunan antar warga. Nenui Nyimah menjadi suatu kewajiban bagi masyarakat Lampung, khususnya masyarakat Lampung Tengah untuk menajaga silaturahmi tetap terjaga antar ikatan keluarga secara geneologis. Pada dasarnya Nemui Nyimah harus dilandasi rasa ikhlas dari lubuk hati yang dalam agak kerukunan hidup lingkungan keluarga dan masyarakat dapat tercipta dengan baik.

\section{c. Nengah Nyappur}

Setiap orang dituntut agar memiliki kemampuan dalam berkomunikasi yang baik sesuai dengan kodratnya sebagai makhluk sosial (Haryadi, 1996). Hal ini harus dimiliki oleh masyarakat Lampung, 
yang disebut dengnan Nengah Nyappur. Masyarakat Lampung memiliki kemampuan dalam bersosialisasi dan bergaul dengan baik di kehidupan sosialnya. Segala permasalahan yang ditemui dalam kehidupan mampu diselesaikan dengan baik melalui jalur komunikasi atau musyawarah.

Anggota masyarakat Lampung dikenal sebagai masyarakat yang memiliki rasa kekeluargaan tinggi, didukung dengan sikap yang mudah bergaul dan bersahabat tanpa memandang suku, ras, agama, status sosial, asal-usul maupun golongan tertentu (Ariyani dkk, 2014). Dengan menerapkan prinsip nengah nyappur, maka akan menumbuhkan sikap toleransi. Ketika seseorang diberi nasihat, maka dengan senang hati akan mendengarkannya, terhadap perkembangan gejala-gejala sosial akan meningkatkan kreativitas untuk mampu mengikuti perubahan. Dapat disimpulkan bahwa nengah nyapur menunjukkan nilai-nilai musyawarah dalam mencapai mufakat. Masyarakat Lampung khusunya Lampung Tengah dikenal sebagai masyarakat yang mudah menyesuaikan terhadap perubahan yang terjadi.

\section{d. Sakai-Sambayan}

Sekelompok masyarakat dalam memperta hankan hidupnya dituntut agar pandai bekerjasama dengan orang lain (Haryadi, 1996). Agar tercipta suatu hubungan kekerabatan yang baik maka masyarakat Lampung suka menolong dan bergotong royong. Gemar tolong menolong, gotong royong, paham akan kebersamaan dan kehidupan guyup ini menjadi nilai-nilai yang disebut dengan sakai sambayan (Ariyani dkk, 2014). Saat ini, nilainilai gotong royong sudah mulai muncul dikarenakan dampat globalisasi yang menyebabkan tingginya individualistis. Saat ini banyak yang beranggapan bahwa segala sesuatu bisa diselesaikan dengan uang, berbeda dengan masyarakat Lampung memiliki rasa solidaritas yang tinggi terhadap kegiatan-kegiatan sosial.

Selain itu, dalam masyarakat Lampung juga dikenal istilah titie gemati yang berarti sopan santun berdasarkan kebiasaan yang dilakukan masyarakat Lampung. Kehidupan masyarakat Lampung memiliki tatanan hidup yang teratur karena prinsip yang terkandung dalam titie gematie. Prinsip hidup ini dijadikan pedoman masyarakat Lampung untuk mengendalikan diri, sehingga terbentuk norma hukum atau disebut dengan cepalo sesuai dengan kebutuhan hidup masyarakat.

Nilai- nilai masyarakat suku Lampung yang telah diuraikan merupakan suatu kebutuhan dasar kehidupan seluruh anggota masyarakat agar tercermin dalam kehihdupan sehari-hari baik secara individual maupun bermasyarakat. Unsur - unsur tersbut menjadi nilai dasar yang menjadi landasan kepribadian suku Lampung atau falsafah hidup suku Lampung. Nilai-nilai tersebut tercermin dalam pola tingkah laku dan pergaulan hidup dengan masyarakat lain. Oleh karena itu sebuah keluarga yang telah bermartabat adat, memiliki kewajiban untuk terus melestarikan nilai - nilai Piil Pesenggiri, (Hadikusuma, H. (1989).

\section{Kandungan Nilai Dalam Piil Pesenggiri}

Falsafah Piil Pesenggiri semakin lama semakin memudar dari kehidupan sosial masyarakat Lampung, hal ini ditunjukan dari munculnya stereotip masyarakat diluar Lampung terhadap suku Lampung. Proses menurunnya penerapan falsafal Piil Pesenggiri ini karena jumlah populasi suku Lampung yang menurun di provinsi Lampung. Sehingga mereka semakin tersudutkan oleh suku suku lain yang lebih dominan mendiami wilayah Lampung.

Kurangnya sosialisasi tentang nilai - nilai falsafah suku Lampung terhadap masyarakat luar juga mengakibatkan munculnya stereotip yang kurang baik. Karena populasi dari masyarakat Lampung yang semakin sedikit agar tidak mudah termakan oleh arus perubahan zaman dan modernisasi. Perlu membangun kembali falsafah Piil Pesenggiri sebagai identitas masyarakat Lampung.

Kandungan nilai ini harus terus digali dan dioptimalkan semaksimal mungkin agar mampu memberikan kontribusi yang berkesinambungan dalam kehidupan masyarakat Lampung. Secara umum kandungan nilai yang dapat digali melalui Piil Pesenggiri dapat diuraikan sebagai berikut.

\section{a. Harga Diri}

Kandungan nilai utama dalam Piil Pesenggiri adalah harga diri, karena kata piil mengandung makna harga diri dalam bahasa Lampung. Harga diri disini mengandung arti menjaga menjaga tatanan adat yang telah diatur dalam Piil Pesenggiri, setiap anggota suku Lampung menjadikan Piil Pesenggiri menjadi acuan dalam menjaga nama baik individu atau kelompok mereka. Maslow (Alwisol, 2009) menjelaskan bahwa unsur dalam harga diri yaitu self respect dan respect from other. Self respect merupakan usaha untuk menghargai diri sendiri, sedangkan respect from other merupakan penilaian positif yang diberikan orang diluar dirinya sendiri.

Suku Lampung harus memiliki harga diri yang kuat untuk tetap menjaga nilai - nilai leluhur mereka, karena semakin kecilnya jumlah anggota suku 
Lampung di tanah leluhur mereka sendiri akan menyebabkan acuan harga diri mereka mudah terinfeksi dari budaya di luar suku Lampung. Demo (Guindon, 2010) mengungkapkan bahwa harga diri dapat dipengaruhi oleh berbagai hal seperti, perubahan peran, penampilan, harapan sertarespon dari orang lain. Respon dari orang lain memiliki potensi paling besar dalam mempengaruhi harga diri.

\section{b. Kemandirian}

Kemandirian merupakan salah satu kandungan nilai di dalam Piil Pesenggiri, karena sebagai falsafah suku Lampung Piil Pesenggiri membentuk pribadi - pribadi yang mandiri pada setiap anggota suku Lampung. Hal ini dilakukan agar suku Lampung tetap mampu berkarya walaupun mereka telah menjadi kaum minoritas ditanah kelahirannya. Kemandirian merupakan sikap kunci yang harus dimiliki setiap individu atau kelompok tertentu untuk tetap mempertahankan eksistensi mereka dalam lingkungan sosial. Menurut Nurhayati (2011) kemandirian merujuk pada kemampuan psikososial, seperti kebebasan untuk bertindak atau mengatur dirinya sendiri sehingga tidak tergantung dengan kempuan orang lain, pengaruh lingkungan luar, atau segala sesuatu diluar diri seorang individu.

Robert Havighurst (Desmita, 2014) mengungkapkan bahwa kemandirian memiliki empat bentuk yaitu, kemandirian emosi, kemandirian ekonomi, kemandirian intelektual dan kemandirian sosial. Melalui Piil Pesenggiri suku Lampung diajarkan nilai - nilai yang membuat mereka memiliki harga diri yang tingi sehingga memberikan efek pada sikap kemandirian mereka. Sikap kemandirian suku Lampung di turunkan melalui unsur nemui nyimah, melalui nilai ini masyarakat Lampung diajarkan untuk saling memberi baik dalam keadaan suka dan duka. Melalui nemui nyimah masyarakat Lampung diajarkan untuk tidak mudah tergantung dengan orang lain karena harus mampu berbagi walaupn dalam kondisi sulit. Sehingga akan memberikan efek sikap kemandirian pada masyarakatnya.

\section{c. Nilai Religius}

Religius menurut Sjarkawi (2008) adalah sebuah nilai yang sumbernya berasal dari keyakinan keTuhanan yang dianut oleh manusia. Nilai - nilai religiulitas ini harus tetap dijaga demi menciptakan kehidupan masyarakat yang adil dan makmur. Suku Lampung mengimplementasikan nilai - nilai religius mereka kedalam pill pesenggiri agar nilai - nilai tersebut dapat tumbuh dan diwariskan kepada setiap generasi.

Nilai religiulitas ini dimaknai dari penambahan kata Pesenggiri (lomba) yang diperoleh melalui proses islamisasi, karena sebelumnya falsafah suku Lampung hanya disebut dengan Piil (harga diri). Melalui penambahan kata Pesenggiri menjadikan, falsafah suku Lampung tidak lagi diartikian sebagai harga diri etnisnya, tapi lebih mengedepankan pemaknaan saling berlomba untuk menerapkan semua nilai - nilai kebaikan yang ada dalam Piil Pesenggiri (Juluk Adek, Nemui Nyimah, Nengah Nyappur, Sakai Sambayan). Hal ini merujuk pada konsep Fatabiqul Khairat (QS, Al-Baqarah:148) yaitu kewajiban untuk saling berlomba pada kebaikan. Penambahan kata Pesenggiri menjadikan falsafah ini lebih terbuka terhadap proses interaksi dan sosialisasi di dalam masyarakat.

Piil Pesenggiri memiliki kandungan nilai religius yang sangat kental, karena pada awal mula pembuataanya mengadopsi nilai - nilai Islam. Semula falsafah suku Lampung hanya dinamakan piil yang bermakna harga diri bagi suku Lampung, namun saat islam masuk lalu terjadilah alkuturasi budaya sehingga menghasilkan falsafah baru yang disebut Piil Pesenggiri. Piil Pesenggiri sebagai falsafah sangatlah religious karena mengajarkan banyak nilai - nilai yang luhur seperti, toleransi, harga diri untuk tidak berbuat buruk, musyawarah, gotong royong, suka menolong dan berbagai nilai nilai luhur lainnya.

\section{d. Nilai Gotong Royong}

Nilai gotong royong pada Piil Pesenggiri dapat tercermin pada salah satu unsur yaitu sakai sambayan. Prinsip sakai sambayan mengajarkan suku Lampung untuk saling membantu atau bergotong royong dalam hal apapun. Gotong royong menurut Koentjaraningrat (Sudrajat, 2014) merupakan sebuah tambahan tenaga yang berasal dari luar lingkungan keluarga, yang ditujukan untuk membantu saat terjadi masa - masa sibuk dalam aktifitas sosial kemasyarakatan.

Gotong royong dalam suku Lampung sudah menjadi budaya yang sangat kental. Berbagai jenis kegiatan di dalam suku Lampung dilakukan secara bergotong royong hal ini sebagai bentuk penerapan prinsip - prinsip piil pesenggri. Hampir semua aktifitas sosial dilakukan secara gotong royong seperti, pesta perkawinan, pembuatan rumah, acara - acara adat, panen ladang, dan bentuk - bentuk aktifitas lain yang membutuhkan bantuan orang banyak. 
Aktifitas tolong - menolong ini merupakan bentuk gotong royong yang masih murni karena dilakukan tanpa ada perintah atau arahan dari pamong desa. Hal ini senada dengan pendapat Bintarto (Sudrajat, 2014) bahwa gotong royong yang dilakukan tanpa ada unsur pengarahan ketua adat atau pamong desa merupakan aktifitas gotong royong yang masih khas karena dilandasi prinsip ketulusan tolong menolong. Hal ini merupakan hasil buah penerapan Piil Pesenggiri yang melekat pada setiap aktifitas masyarakat Lampung sehingga mampu menghadirkan prinsip kebersamaan dan tolong - menolong yang masih kental.

\section{e. Toleransi}

Toleransi meupakan sebuah prinsip pokok dalam kehidupan sosial kemasyarakatan. Melalui toleransi seseorang akan belajar bagaiman cara untuk menghargai dan menghormati orang lain. Toleransi juga mengajarkan memandang perbedaan sebagai sebuah keniscayaan dalam hidup. Fatchul Mu'in (2011) merupakan sebuah sikap menghormati orang lain yang memiliki perbedaan dengan diri kita walaupun mereka menentang atau memusuhi kita sekalipun. Sedangkan Samani dan Hariyanto (2013) mengungkapkan bahwa toleransi merupakan sebuah sikap menerima orang lain secara terbuka walaupun orang lain itu memiliki perbedaan latar belakang, sikap dan cara pandang.

Melalui Piil Pesenggiri suku Lampung diajarkan sikap keterbukaan melalui prinsip nengah nyappur. Melalui prinsip ini suku Lampung diajarkan untuk berkomunikasi dan bersosialisasi secara terbuka kepada siapapun dan selalu menyelesaikan masalah dengan prinsip musyawarah. Hal inilah yang menyebabkan suku Lampung sangat toleran dan terbuka dengan individu atau kelompok diluar mereka. Hal ini dapat dilihat dari sikap suku Lampung yang begitu terbuka dan toleran terhadap kedatangan kaum pendatang (transmigrasi). Suku Lampung dengan suka rela berbagi wilayah dengan kaum pendatang, mereka juga terbuka dn saling membantu dalam setiap aktifitas sosial kemasyarakatan. Semua sikap ini merupakan perwujudan dari penerapan falsafah hidup mereka yaitu piil pesenggri secara kompleks dalam setiap aktifitas kehidupan sosial suku Lampung.

Masih luasnya kandungan nilai dalam Piil Pesenggiri masih memungkinkan terdapat nilai nilai lain yang belum tedeskripsikan. Kandungan nilai - nilai dalam Piil Pesenggiri akan terus bergerak mengikuti arus perkembangan sosial masyarakat Lampung. Hal ini disebabkan ada prinsip fleksibelitas dalam nilai - nilai Piil Pesenggiri yang akan selalu hadir dalam memberikan dukungan demi kemajuan masyarakat Lampung dalam mengarungi bahtera kehidupan sosial masyarakatnya.

\section{Membangun Identitas Ulun Lampung dalam Masyarakat Multikultural}

Sebagai sebuah identitas suku Lampung mulai kehilangan jati diri mereka, karena semakin sedikitnya populasi suku Lampung. Piil Pesenggiri menjadi identitas kesukuan yang harus dijaga agar identitas suku Lampung tidak menghilang disebabkan proses asimilasi dan alkuturasi budaya yang begitu deras. Piil pesenggriri harus mampu hidup dalam setiap aktifitas sosial suku Lampung untuk tetap bertahan sebagai sebuah identitas mutlak suku Lampung. Rekontruksi budaya digunakan sebagai sebuah kunci dalam membentuk persepsi yang lebih baik pada lingkungan sosial, dengan pemahaman atas identitas diri mereka dapat dilakukan dengan pemaknaan secara meluas untuk memudahkan ruang gerak mereka di dalam lingkungan sosial (Rokhani, Salam, Rochani : 2016)

Identitas budaya menjadi sebuah aspek krusial yang dihadapi suku Lampung untuk menjaga eksistensi mereka kehidupan sosial masyarakat. Melalui identitas budaya diharapkan diharapakan individu memiliki karakteristik yang membedakan dengan individu suku lain (Samovar (2010). Identitas budaya merupakan suatu konsep bisa dikonstruksi secara alamiah dalam proses interaksi sosial masyarakat multietnik (Haryono, 2016)

Hal inilah yang menjadi landasasan untuk membangun kembali identitas suku Lampung agar mereka mampu menunjukan jati diri mereka sehingga semua stereotip negative dapat dihilangkan. Sehingga setiap anggota suku Lampung harus memiliki karakter yang berbeda dengan suku lain, melalui pencerminan nilai - nilai yang terdapat dalam Piil Pesenggiri. Untuk menjaga itu eksistensi piil pesenggri harus dilakukan kontruksi budaya seperti yang dijelaskan oleh (Samovar, 2010), bahwa kontruksi budaya dapat dimulai penanaman nilai ketika anggota suku Lampung masih anak - anak, dilanjutkan proses implementasi saat mereka menginjak ramaja, dan saat mereka dewasa nilai - nilai Piil Pesenggiri telah matang dan merasuk kedalam karakter suku Lampung.

Saat ini identitas ulun Lampung mulai memudar dikarenakan banyaknya pendatang. Lampung menjadi salah satu daerah tujuan migrasi sehingga mempengaruhi posisi ulun saat ini. Dampaknya, 
ulun Lampung sebagai etnis lokal semakin terdesak oleh kebudayaan masyarakat lain dan cenderung kurang dihargai. Berdasarkan hal ini suku Lampung harus mampu mengembalikan eksistensi mereka dengan tetap mempertahankan ciri budaya mereka. Robbins \& Judge (2008) menjelaskan bahwa untuk menjaga eksistensi sebuah kelompok, harus mengembalikan peran budaya menjadi sebuah substansi yang ekslusif, untuk menjawabnya budaya harus mampu bertansformasi seperti berikut.

Pertama budaya mampu menunjukan adanya perbedaan dari segi kualitas nilai, dan karakter yang terlihat dari sebuah suku, kedua budaya mampu menciptakan identitas rasa bagi anggotanya, ketiga budaya mampu memberikan kemudahan berkomitmen secara luas untuk mempersempit ruang gerak sikap individualis. Dengan kembalinya peran budaya maka ekspresi identitas dapat dimunculkan kembali dalam berbagai bentuk. Agar tidak Dalam pergaulan di masyarakat, masyarakat Lampung juga tidak mengalami diskriminasi (Abbas:2016).

Di tengah situasi Lampung yang sebagian besar dihuni oleh pendatang seperti Jawa, ulun Lampung terlihat sangat mudah menerima berbagai perubahan yang terjadi karena banyak pendatang. Hal itu menyebabkan sulitnya mengenali budaya suku Lampung dan identitas budayanya. Saat ini, para pendatang tidak berusaha beradaptasi menjadi "seperti orang Lampung" dikarenakan nilai-nilai budaya Lampung tidak hadir di lingkungan mereka. Hal sebaliknya terjadi di ulun Lampung yang mengidentifikasikan dirinya sebagai pendatang misalnya dengan mengikuti bahasa pendatang dan akhirnya penggunaan bahasa lokal semakin berkurang.

Memaknai ulang tradisi dan budaya Piil Pesenggiri merupakan proses identifikasi dan pembentukan ulang identitas ulun Lampung agar dapat bertahan di tengah masyarakat pendatang. Piil Pesenggiri perlu dipahami ulang oleh ulun Lampung dalam konteks kesejarahan di masa lalu kemudian diterapkan ulang agar sesuai dengan perkembangan zaman saat ini. Kesadaran dalam membangun kembali jati diri ulun Lampung akan mengangkat kembali martabatnya sebagai penduduk lokal.

Di dalam Piil Pesenggiri terdapat norma-norma yang secara ideal berbudi luhur. Yang menjadi permasalahan yaitu keragaman dalam menerapkan Piil Pesenggiri ini yang berkonotasi negative. Hal ini dapat memicu terjadinya konflik dengan pendatang. Dalam menyikapi globalisasi, Piil Pesenggiri sebagai nilai-nilai fundamental yang berusia ratusan tahun perlu dihidupkan kembali dan dibentuk ulang. Berdasarkan pandangan Comaroff \& Comaroff (2009), selain membentuk representasi identitas budaya, mengaktifkan kembali Piil Pesenggiri merupakan salah satu perjuangan etnis yang termarginalisasi. Oleh karena itu, masyarakat Lampung perlu melestarikan filsafat hidup Piil Pesenggiri agar masyarakat Lampung tidak kehilangan identitas sebagai ulun Lampung dan agar mampu berinteraksi dengan masyarakat multukultural dengan tetap mempertahankan identitas budaya ulun Lampung.

Berikut ini ada beberapa hal yang perlu dilakukan untuk membangun kembali identitas masyarakat Lampung di tengah-tengah kemajemukan masyarakat, yakni:

\section{a. Menerapkan piil peseggiri dimanapun} berada.

Mempertahankan Piil Pesenggiri dilakukan dengan menerapkan aspek aspek piil peenggiri di manapun mereka berada dalam interaksi sosial. Interaksi sosial dengan prinsip Piil Pesenggiri sangat dibutuhkan untuk melestarikannya. Interaksi sosial akan terjadi ketika dua atau lebih orang bertemu, bertegur sapa, berjabat tangan dan saling menatap satu sama lain (Siregar, 2014). Interaksi sosial menjadi syarat utama terjadinya aktivitas social, apabila dalam suatu masyarakat terdapat kegiatan bersama atau aktivitas sosial yang dilakukan secara berulang-ulang dan tetap maka akan menciptakan sebuah hubungan masyarakat yang baik. Masyarakat Lampung mewarisi sifat atau pandangan hidup dalam Piil Pesenggiri yaitu nengah nyappur. Aspek ini memiliki arti bahwa masyarakat Lampung memiliki sifat mudah bergaul dan membaur di lingkungan di manapun berada. Hal ini dapat dilihat dari hasil penelitian Minandar (2018) menunjukkan bahwa masyarakat Lampung tidak hanya berteman dengan sesama masyarakat Lampung saja, tetapi juga dapat menerima perbedaan dari suku lain.

b. Meningkatkan kesadaran dalam melesta rikan budaya Piil Pesenggiri.

Melestarikan budaya Piil Pesenggiri menjadi tugas dan tanggungjawab seluruh masyarakat suku Lampung. Suku Lampung mnejadi suku minortitas di tanah kelahirannya sendiri, oleh karena itu perlu kesadaran bagi suku Lampung untuk bekerja sama dalam membangun kembali identitas ulun Lampung. Kesadaran dalam melestarikan budaya diperlukan kerja sama semua phak termasuk masyarakat pendatang. Seperti pepatah "diaman bumi berpijak, 
disitu langit dijunjung" dapat menjadi prinsip bagi pendatang yang menempati daerah Lampung. Kerjasama yang kuat dan toleransi dari masyarakat pendatag akan menghasilkan sesuatu yang signifikan bagi kelestarian budaya Piil Pesenggiri di tengah-tengah masyarakat yang multikultur.

\section{c. Peran tokoh adat.}

Melestarikan nilai-nilai Piil Pesenggiri ini dilakukan sebagai bentuk kepedulian dan upaya dalam melestarikan budaya bangsa dan negara Indonesia. Piil Pesenggiri dapat menjadi senjata untuk mengatasi sebuah konflik dalam masyarakat, karena dalam menghadapi sebuah konflik diperlukan sebuah bentuk kebudayaan yang di dalamnya mengandung nilai - nilai yang sakral, karena budaya memiliki sebuah kekuatan untuk memaksakan eksistensinya kepada masyarakat yang mendukunya untuk menaati segala bentuk aturan dan nilai yang melekat (Safitri, A \& suharno, 2020).

Peran tokoh adat sangat penting dalam melestarikan budaya dengan memberikan sosialisasi kepada masyarakat tentang nilai-nilai yang harus dijunjung tinggi dalam budaya Piil Pesenggiri. Pemegang adat ini menjadi kunci dalam pembudayaan nilai-nilai Piil Pesenggiri mulai dari anak anak atau generasi penerus bagi ulun Lampung. Masyarakat perlu bekerja sama secara intens dengan tokoh adat lainnya atau dengan pemerintah daerah setempat dalam melakukan sosialisasi budaya Piil Pesenggiri. Selain itu, mengajarkan nilai-nilai budaya Piil Pesenggiri juga dapat dilakukan oleh guru terhadap siswanya dengan memberikan pemahaman Piil Pesenggiri sebagai kearifan lokal yang ada di Lampung.

\section{KESIMPULAN}

$\square$ iil Pesenggiri merupakan prinsip dan harga diri ulun Lampung. Apabila prinsip-prinsip Piil Pesenggiri dilaksanakan sebagai suatu kesatuan, maka harga diri seseorang dengan sendirinya akan baik atau memiliki prestise yang tinggi. Piil Pesenggiri sebagai identitas ulun Lampung yang membedakan dengan masyarakat lainnya. akan tetapi saat ini identitas budaya Piil Pesenggiri mulai kabur dikarenakan Lampung menjadi daerah tujuan migrasi dan perkembangan masyarakat sebagai dampak dari globalisasi sehingga ulun Lampung mulai meninggalkan nilainilai Piil Pesenggiri.

Untuk melestarikan budaya Piil Pesenggiri di tengah-tengah kemajemukan suku dan budaya, diperlukan membangun kembalil nilai-ninlai ulun Lampung dengan melihat sejarah masa lampau dan disesuaikan dengan perkembangan saat ini. Membangun kembali nilai-nilai Piil Pesenggiri diperlukan kerjasama seluruh masyarakat mulai dari tokoh adat, masyarakat Lampung untuk memberikan sosialisasi kepada masyarakat terutama bagi gerenrasi penerus sejak dini. Pemerintah daerah perlu memberikan perhatian khusus kepada ulun Lampung untuk menghidupkan kembali Piil Pesenggiri mengingat suku Lampung menjadi suku minoritas yang menempati Lampung. Prinsip- prinsip Piil Pesenggiri yang terdiri dari Juluk Adek, nemui nyimah, nemui nyappur dan sakai sambyan perlu dijunjung tinggi di manapun masyarakat Lampung berada.

\section{E. UCAPAN TERIMAKASIH}

$\mathrm{T}$ erimakasih penulis sampaikan kepada bapak Samsuri selaku dosen pembimbing yang dengan sabar memberikan bimbingan, masukan, arahan serta dukungan kepada penulis dalam menyusun artikel ini. Terimakasih juga penulis sampaikan kepada Program Pascasarjana Universitas Negeri Yogyakarta yang telah memberi dukungan untuk penerbitan artikel.

\section{DAFTAR PUSTAKA}

Abbas. M.R. (2016). Identitas Ke-Papua-An Di Kota Multi Kultural (Refleksi Kota Yogyakarta Dalam Kajian Identitas. Jurnal Politik Profetik Volume 04, No. 1

Afriansyah, A. (2015). Foreigners land rights Regulations: Indonesia's Practice. Jurnal Mimbar Hukum, 27(1): 98-116. Retrieved from https://journal.ugm.ac.id//mh/article/view/15913.

Alwisol. (2009). Psikologi kepribadian. Malang. UMM Press.

Ariyani, F., Yufrizal, H., Agustina, E. S., Mustofa, A. (2014). Konsepsi Piil Pesenggiri menurut masyarakat sdat Lampung Waykanan di Kabupaten Waykanan (Sebuah Pendekatan Discourse Analysis). Lampung: Aura Printing \& Publishing Anggota IKAPI.

Comaroff, J. L \& Comaroff, J. (2009). Ethnicity. Inc. Chicago and London: The University of Chicago Press.

Cole, M \& Parker, M. (2011). Culture and cognition. In K. D. Keith (Ed.), Cross-cultural

Danial \& Wasriah. (2009). Metode penulisan karya ilmiah. Bandung: Laboratorium Pendidikan Kewarganegaraan UPI.

Desmita. (2014). Psikologi Perkembangan Peserta Didik. Bandung: PT. Remaja Rosdakarya. 
Fachruddin. (2007). Falsafah Piil Pesenggiri sebagai kearifan Kota Lampung teraktualisasi melalui pendidikan non formal. Perspektif IImu Pendidikan, Vol. 15 Th. 8. Retrieved from https://doi.org/10.21009/PIP.151.12.

Facruddin \& Haryadi. (1996). Falsafah Piil Pesenggiri sebagai norma tatakrama kehidupan sosial masyarakat Lampung. Bandar Lampung: CV. Arian Jaya.

Fatchul Mu'in. Pendidikan Karakter. (2011). Yogyakarta: Ar-Ruzz Media.

Gill, T. G. (2013). Culture, Complexity, and Informing: How Shared Beliefs Can Enhance Our Search for Fitness, Informing Science: the International Journal of an Emerging Transdiscipline, Vol. 16, pp. 72 97.

Guindon, M.H. (2010). Self-esteem across the lifespan. New York: Taylor and Francis Group, LCC.

Hadikusuma, H. (1989). Masyarakat dan adat budaya Lampung. Bandung: Mandar Maju.

Haryono, T.J.S. (2016). Konstruksi Identitas Budaya Bawean. BioKultur, Vol.V/No.2. hal. 166

Imron, A \& Pratama, R.A. (2020). Perubahan Pola-Pola Perkawinan Pada Masyarakat Lampung Saibatin. Jurnal Antropologi: Isu-Isu Sosial Budaya. VOL. (01), 121-130.

Jahoda, G. (2012). Critical reflections on some recent definitions of "culture", Culture \& Psychology, Vol. 18(3) 289-303. DOI: 10.1177/1354067X12446229.

Kurniawan, A \& Rudyansjah, T. (2016). Kajian Mengenai Perubahan Afiliasi Pada Sistem Organisasi Sosial Masyarakat Lematang. Jurnal Antropologi: Isu-Isu Sosial Budaya. Vol. 18 (2), 89-103.

Minandar, C.,A, (2018). Aktualisasi Piil Pesenggiri sebagai falsafah hidup nahasiswa Lampung di tanah rantau. Sosietas, vol 8, no 2. Retrieved from http://ejournal.upi.edu/ index.php/sosietas/article/view/14594.

Na'im, A \& Syaputra, H. (2010). Kewarganegaraan, suku bangsa, agama, dan bahasa sehari-hari penduduk Indonesia. Jakarta: Badan Pusat Statistika.

Nurhayati, E. (2011). Psikologi Pendidikan Inovatif. Yogyakarta: Pustaka Pelajar.

Robbins SP \& Judge. (2008). Perilaku Organisasi. Buku 2, Jakarta: Salemba Empat.

Rokhani .U., Salam. A., Rochani. I. (2016). Rekonstruksi Identitas Ke-"Tionghoa"-An Dalam Film Indie PascaSuharto. Jurnal Rekam, Vol. 12. No. 1

Safitri, A \& Suharno. (2020). Budaya Siri' Na Pacce Dan Sipakatau Dalam Interaksi Sosial Masyarakat Sulawesi Selatan. Jurnal Antropologi: Isu-Isu Sosial Budaya. Vol. 22 (01), 102-111.

Samovar, Larry A., dkk ( 2010). Komunikasi lintas budaya edisi 7. Jakarta: Salemba Humanika.

Samani, M dan Hariyanto. (2013). Konsep dan Model Pendidikan Karakter. Bandung: PT Remaja Rosdakarya.

Siregar, A. H. (2014). Pola asuh keluarga migran asal Sumatera Utara. (Skripsi). Universitas Pendidikan Indonesia, Bandung.

Sjarkawi. (2008). Pembentukan Kepribadian Anak. Jakarta: Bumi Aksara.

Sudrajat, A. (2014). Nilai-Nilai Budaya Gotong Royong Etnik Betawi Sebagai Sumber Pembelajaran IPS. Disertasi, Sekolah Pascasarjana, Universitas Pendidikan Indonesia.

Yuauf, H. (2013). Dimensi epistemologis filsafat hidup Piil Pesenggiri dan relevansinya bagi moralitas Islam. Lampung: Fakultas Ushuluddin IAIN Raden Intan Lampung. 